\title{
Quality of Life and Sexual Functioning of Women after Breast Cancer Surgery
}

\author{
Stana Pacaric ${ }^{1,2,3} \mathbb{D}$, Želimir Orkić ${ }^{2,3}$, Andrea Milostić-Srb ${ }^{1 *}(\mathbb{D})$ Tajana Turk ${ }^{2,3}$ (D), Nikolina Farčić ${ }^{1,2,3}$, Štefica Mikšić ${ }^{1}$, \\ Silvia Adamčević ${ }^{3}$, Ivan Erić ${ }^{2,3}$ iD, Zvjezdana Gvozdanović ${ }^{1,2,4}$, Nika Srb $^{2}$ iD \\ ${ }^{1}$ Department of Nursing and Palliative Medicine, Faculty of Dental Medicine and Health, Josip Juraj Strossmayer University of \\ Osijek, Nursing Institute "Professor Radivoje Radić", Osijek, Croatia; ${ }^{2}$ Faculty of Medicine, Josip Juraj Strossmayer University \\ of Osijek, Osijek, Croatia; ${ }^{3}$ Department of Surgery, University Hospital Centre Osijek, Osijek, Croatia; ${ }^{4}$ Head Nurse, General \\ County Hospital Našice, Našice, Croatia
}

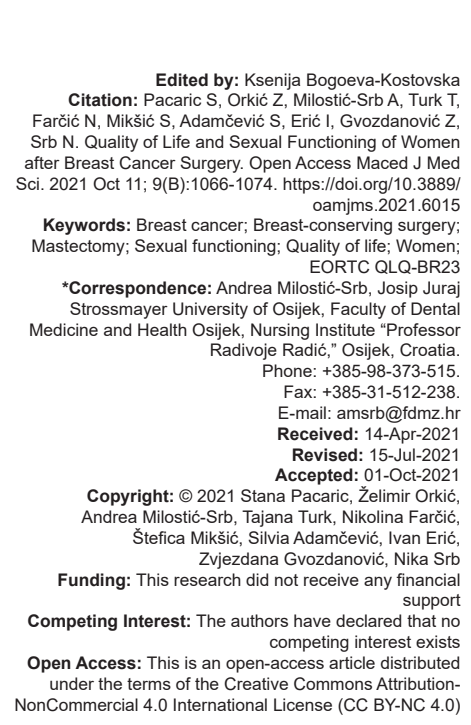

\section{Abstract}

BACKGROUND: Women with breast cancer can experience changes in sexual functioning and body images that can seriously affect their quality of life.

AIM: The aim of this research was to study the quality of life and sexual functioning of women after a mastectomy and after a breast-conserving surgery and to compare post-operative quality of life.

SUBJECTS AND METHODS: This cross-sectional study included 204 participants, 101 patients after a mastectomy and 103 patients after a quadrantectomy. The research was conducted using the Croatian version of the questionnaire of the European Organization for Research and Treatment of Breast Cancer, the questionnaire with the breast cancer module EORTC QLQ - BR 23

RESULTS: On the EORTC QLQ -BR23 scale, participants with mastectomy rated their sexual functioning $(p<0.001)$, sexual pleasure $(p<0.001)$, and systemic side effects $(p=0.04)$ lower comparing to women after breastconserving surgery. The overall functionality scale was significantly lower $(p=0.03)$ for women who underwent mastectomy compared to those who underwent breast-conserving surgery. Participants under 51 years of age had worse body image 1 month after mastectomy $(p=0.006)$, while sexual functioning was better $(p=0.03)$ than in olde age groups. In breast-conserving surgery group, 1 month after surgery, participants in the age group of 61 years and older assessed body image better $(p=0.04)$ than in the younger age group. Sexual functioning was rated better by women aged $51-60$ years $(p=0.03)$.

CONCLUSION: Results of this study show that women after breast conserving surgery have better quality of life better sexual functioning and less side effects of systemic therapy compared to women after mastectomy. The type of surgery, patient's age and time passed after completion of treatment are important factors which influence sexual functioning and quality of life in breast cancer survivors.

\section{Introduction}

Breast cancer is the most commonly diagnosed cancer and the leading cause of cancer death in women, accounting for $23 \%$ of total cancers and $14 \%$ of deaths [1]. In the Republic of Croatia, breast cancer is a significant public health problem, the second most common cause of death. In 2015, age-standardized population rates for incidence were 126.3/100,000 and mortality was $47.7 \%$. The number of cases per year in Croatia is $2748,26 \%$ of total number of cancer cases [2].

Nowadays, cancer is considered a serious and potentially life-threatening disease, even a deadly disease, such as some advanced cancers, which has an impact on the mental and physical health of patients [3]. Breast cancer treatment is often based on a multimodal approach depending on the stage and biology of the tumor and the acceptance and tolerance of the patient. Breast cancer treatment includes surgery and systemic therapy (endocrine therapy, chemotherapy, and targeted therapy) [4]. Diagnosis of breast cancer and treatment can have a significant impact on the quality of life of patients [5]. Breast is often considered as a body part with greatest association with femininity, sexuality, and motherhood [6].

Surgery is the basic therapeutic procedure in patients with breast cancer. Two methods are used: Breast-conserving therapy (BCT) and mastectomy. BCT allows women to maintain their breasts and appearance, with similar long-term survival outcomes and similar recurrence rates compared to mastectomy [4]. An increasing number of studies show an improvement in the overall survival of women treated with BCT regardless of the cancer phenotype compared to mastectomy as well as an impact on psychological health, such as depression [3], [4]. 
Despite the fact that $\mathrm{BCT}$ is at least equal to the results of mastectomy, many women with small breast cancer still opt for mastectomy, and several studies in the past decade have shown a trend of increase of unilateral and bilateral mastectomies [5], [6]. Many women who have survived breast cancer, especially those who have had a mastectomy, are dissatisfied with their physical appearance and opt for breast reconstruction to restore the contour of the body, improve their self-image and quality of life [6]. The results of a study conducted in Brazil showed that patients who underwent breast reconstruction after mastectomy reported better sexual function and body image and fewer depressive symptoms than patients who underwent mastectomy alone [7]. The quality of life of breast cancer patients is gaining increasing attention due to the increasing number of new cases, higher survival rates in recent decades and the important role of women in the family [8]. According to the World Health Organization, quality of life is defined as an individual's perception of their life position in the context of the culture and value system in which they live and in relation to their goals [9].

Hair loss due to chemotherapy, poor mental health such as anxiety and depression, lower selfesteem, and lack of understanding of the partner all has an impact on sexual functioning. Most sexual problems were associated with vaginal dryness, pain during sex, and vasomotor symptoms [10], [11]

When considering sexuality, it is important to distinguish sexuality from sexual functioning. Sexual functioning includes components such as vaginal lubrication, frequency of sexual intercourse, and breast tenderness [12], [13].

Studies investigated sexual functioning and quality of life in women after surgery and treatment, found reduction in sexual dysfunction from $60 \%$ to $70 \%$. Among 360 sexually active women, half (52\%) reported having a problem in two or more areas of sexual functioning, (24\%) had a serious problem in at least one area, and in (28\%) women sexual problems were associated with vaginal dryness, poorer mental health, and problems with a partner [14]. Sexual changes often become the most difficult aspect of life and the impact of these changes can continue for many years after breast cancer treatment. Sexual dysfunction leads to mental and physical disorders for women who have survived breast cancer [15]. In this study, we have used a modular breast cancer questionnaire (QLQ-BR23) that evaluates subscale outcomes: Body image, sexual functioning, sexual enjoyment, assessments of the future, systemic side effects, breast symptoms, arm symptoms, and anxiety due to hair loss. The QLQ-BR23 questionnaire was validated in several countries and tested in intercultural studies [16], [17]. Surveys were also conducted with the QLQ-BR-23 questionnaire in Croatia [18], [19].

Therefore, the aim of the study was to examine the quality of life and sexual functioning of women after mastectomy and women after BCT and to compare postoperative quality of life.

\section{Participants and Methods}

\section{Participants and design}

A cross-sectional survey was conducted. During the period from 2015 to 2017, consecutive female patients with breast cancer in the outpatient clinic of the Department of Thoracic, Plastic-Reconstructive Surgery and Arm Surgery of the University Hospital Centre Osijek were divided into two groups: Women who underwent mastectomy and women who underwent quadrantectomy. Both groups of women consisted of patients from 2 time points: 1 month after surgery and 1 year after surgery.

Time point of 1 month after surgery was chosen so that the patients could be studied during postoperative recovery and initiation of adjuvant oncologic therapy.

Time point of 1 year after surgery was chosen so that the patients could be studied after completion of adjuvant oncologic therapy and after adoption period to changes in quality of life due to breast cancer.

\section{Participants}

This study included 250 women with pathohistological findings of Stage I-II breast cancer. Inclusion criteria were women operated for breast cancer (PHD cancer findings, stage I-II) 1 month and 1 year after surgery. Exclusion criteria were women with breast reconstructive surgery, women under 18, women over 75, life expectancy of less than 1 year, women who do not understand Croatian, medical record on past or present existence of psychotic disorders, mental retardation, severe personality disorder and permanent personality changes, earlier participation in any form of psychotherapeutic treatment. During the study, 20 women refused to participate in the survey and 26 women submitted invalid surveys. Of the remaining 204 women, post-mastectomy group consisted of 101 patients (50 women 1 month after mastectomy and 51 women 1 year after mastectomy) and post-BCT group consisted of 103 women (52 women 1 month after quadrantectomy and 51 women 1 year after quadrantectomy).

\section{Sample size}

To observe the mean effect in the difference of numerical variables between two independent groups of examinees, with a significance level of 0.05 and strength 0.8 , the minimum required sample size is 
64 subjects per group, that is, a total of 128 subjects (calculation made using $\mathrm{G}$ * Power version 3.1.2, Franz Faul, University of Kiel, Germany).

\section{Questionnaire}

The first part of the questionnaire contained questions on general data of participants. Sociodemographic questionnaire consisting of age, education, marital status, and data from medical records: Type of surgery, pathohistological findings of breast cancer, type of oncology therapy, date of beginning, and completion of therapy.

\section{EORTC QLQ - BR 23}

The study was conducted by an anonymous survey using the Croatian version of the questionnaire of the European Organization for Research and Treatment of Cancer EORTC with the approval of the aforementioned organization, the questionnaire with the breast cancer module EORTC QLQ - BR 23. The EORTC QLQ - BR 23 questionnaire consists of 23 particles, four functional scales (self-image, sexual functioning, sexuality, and health in the future), while the symptom scale consists of therapy side effects, breast and arm symptoms and hair loss. The display of scales and particles is scored according to the Likert scale of 4 degrees, in the range from 1 (not at all) to 4 (almost always). A higher number of points on the particles indicates better functioning that is a higher number of symptoms [20]. Internal reliability coefficient (Cronbach Alpha) for the overall scale QLQ - BR23 = 0.904 .

\section{Ethical approval}

The study was conducted after the approval of the Ethics Committee of the University Hospital Centre Osijek (reference number 25-1:11425-3/2015). All women were informed about the purpose of the research and the anonymity of data in it, and their participation was voluntary. All participants had signed written informative consent. The research was conducted in accordance with ethical principles and human rights in biomedical research.

\section{Statistical data processing}

Category data were presented in absolute and relative frequencies. Numerical data are described by the median and limits of the interquartile range. Differences in category variables were tested by the Hi-square test, and, if necessary, by Fisher's exact test. The normality of the distribution of numerical variables was tested by the Shapiro-Wilk test. The differences of the normally distributed numerical variables between the two independent groups were tested by the MannWhitney U-test. Differences of numerical variables, in the case of three or more groups, were tested by the Kruskal-Wallis test. All $p$ values are two-sided. The significance level was set to alpha $=0.05$. The statistical program MedCalc Statistical Software version 19.0.5 (MedCalc Software bvba, Ostend, Belgium; https:// www.medcalc.org; 2019) was used for statistical analysis.

\section{Results}

\section{participants \\ Demographic characteristics of the}

The study was conducted on 204 participants, 101 (49.5\%) were women after mastectomy and $103(50.5 \%)$ were after quadrantectomy. The median age of the examinees was 56 years (interquartile range of 50-61 years) ranging from 34 to 72 years, and the median age of the participants on diagnosis of disease was 54 years (interquartile range of 48-60 years) ranging from 34 to 71 years. There were $60(29.4 \%)$ participants under the age of 50,88 (43.1\%) aged 51-60, and 56 (27.5\%) women aged 61 and above (Table 1).

Table 1: Demographic characteristics

\begin{tabular}{lllll}
\hline & Mastectomy & $\begin{array}{l}\text { Breast conserving } \\
\text { therapy }\end{array}$ & Total & p-value \\
\hline $\begin{array}{l}\text { Participants age (median } \\
[25-75 \%])\end{array}$ & $58(49-62)$ & $55(50-60)$ & $56(50-61)$ & $0.18^{*}$ \\
Age when diagnosed (median & $56(48-61)$ & $53(48-58)$ & $54(48-60)$ & $0.12^{*}$ \\
[25-75\%]) & & & & \\
Age groups ( $[\%])$ & $27(26.7)$ & $33(32)$ & $60(29.4)$ & $0.39^{* *}$ \\
$\quad$ Up to 50 years & $42(41.6)$ & $46(44.7)$ & $88(43.1)$ & \\
$51-60$ years & $32(31.7)$ & $24(23.3)$ & $56(27.5)$ & \\
$\quad 61$ and older & $101(100)$ & $103(100)$ & $204(100)$ & \\
$\quad$ Total & & & &
\end{tabular}

Regarding the level of education, most participants had secondary education, 102 of them $(50 \%)$, and regarding the marital status, $138(68 \%)$ women were married, and a total of $144(71 \%)$ lived in some form of partnership. Importance of physical appearance was stated by 61 (29.9\%) examinees. $143(70.4 \%)$ participants were familiar with the method of reconstruction, and 101 (50\%) of them would have agreed to breast reconstruction if the surgeon had recommended it. Examinees with mastectomy also had significantly more chemotherapy $\left(\chi^{2}\right.$ test, $\left.p=0.04\right)$ (Table 2).

Quality of life was also assessed by the QLQ-BR23 scale. One month after surgery, women with mastectomy rated significantly worse sexual function (Mann-Whitney U-test, $p<0.001$ ) and pleasure in sex (Mann-Whitney U-test, $p<0.001$ ), while they had more significant side effects with systemic therapies (Mann-Whitney U-test, $\mathrm{p}=0.04$ ), compared to those 
with quadrantectomy (Table 3).

One year after surgery, sexual functioning (Mann-Whitney U-test, $p<0.001$ ) and sexual pleasure (Mann-Whitney U-test, $p=0.04$ ) were still significantly worse in examinees who had a mastectomy, compared to those after quadrantectomy. The overall functionality scale was significantly lower for patients after mastectomy, compared to those after quadrantectomy (Mann-Whitney U-test, $p=0.03$ ) (Table 4).

One month after surgery, women up to the age of 50 had a significantly worse body image compared to older examinees (Kruskal-Wallis test, $p=0.006$ ). Sexual functioning was significantly better in women up

Table 2: Characteristics of participants regarding education, marital status, and therapy

\begin{tabular}{|c|c|c|c|c|}
\hline & \multicolumn{3}{|c|}{$\begin{array}{l}\text { Number (\%) of examinees in regard to the type } \\
\text { of procedure }\end{array}$} & \multirow[t]{2}{*}{ p-value } \\
\hline & $\begin{array}{l}\text { Mastectomy } \\
(n=101)\end{array}$ & $\begin{array}{l}\text { Breast conserving } \\
\text { therapy }(n=103)\end{array}$ & Total & \\
\hline \multicolumn{5}{|l|}{ Level of education } \\
\hline $\begin{array}{l}\text { Unfinished elementary } \\
\text { school }\end{array}$ & $3(3)$ & $1(1)$ & $4(2)$ & 0.73 \\
\hline Elementary school & $22(22)$ & $25(24)$ & $47(23)$ & \\
\hline High school & $49(49)$ & $53(51)$ & $102(50)$ & \\
\hline Higher education & $13(13)$ & $14(14)$ & $27(13)$ & \\
\hline College education & $14(14)$ & $10(10)$ & $24(12)$ & \\
\hline \multicolumn{5}{|l|}{ Marital status } \\
\hline Single & $3(3)$ & $3(3)$ & $6(3)$ & 0.52 \\
\hline Married & $66(65)$ & $72(70)$ & $138(68)$ & \\
\hline Extramarital unity & $5(5)$ & $1(1)$ & $6(3)$ & \\
\hline Divorced & $8(8)$ & $10(10)$ & $18(9)$ & \\
\hline Widow & $19(19)$ & $17(17)$ & $36(18)$ & \\
\hline Lives alone & $30(29.7)$ & $31(30.1)$ & $61(29.9)$ & $0.99^{\star \star}$ \\
\hline $\begin{array}{l}\text { Their physical appearance is } \\
\text { important to them }\end{array}$ & $73(72.3)$ & $82(79.6)$ & $155(76)$ & $0.25^{\star *}$ \\
\hline $\begin{array}{l}\text { Are familiar with the } \\
\text { reconstruction method }\end{array}$ & $73(72.3)$ & $70(68.6)$ & $143(70.4)$ & $0.65^{\star *}$ \\
\hline $\begin{array}{l}\text { Would agree to breast } \\
\text { reconstruction if the surgeon } \\
\text { recommended it }\end{array}$ & $47(46.5)$ & $54(53.5)$ & $101(50)$ & $0.40^{* *}$ \\
\hline Oncological therapy & $89(88.2)$ & $92(90.2)$ & $181(89.2)$ & 0.63 \\
\hline Chemotherapy & $80(79.2)$ & $50(48.5)$ & $130(63.7)$ & 0.04 \\
\hline Radiotherapy & $54(53.5)$ & $61(59.2)$ & $115(56.4)$ & 0.19 \\
\hline Hormonal therapy & - & $37(18.1)$ & $37(18.1)$ & - \\
\hline
\end{tabular}

to 50 years of age (Kruskal-Wallis test, $p=0.03$ ). One year after surgery, significantly worse sexual functioning (Kruskal-Wallis test, $p<0.001$ ) and significantly more side effects with systemic therapy (Kruskal-Wallis test, $p=0.008)$ was experienced by women aged 61 and over (Table 5).

In participants after quadrantectomy, 1 month after surgery, those up to 50 years of age had a significantly worse perception of their body (KruskalWallis test, $p=0.04$ ), sexual functioning was significantly better in participants aged 51-60 years (KruskalWallis test, $p<0.001)$. Patients under the age of 50 were significantly less concerned (Kruskal-Wallis test, $p=0.02$ ), but they were also significantly more anxious about hair loss (Kruskal-Wallis test, $p=0.03$ ). One year after surgery, sexual functioning was significantly better in women aged 61 years and older (Kruskal-Wallis test, $p<0.001)$. The overall scale of functionality was significantly lower in examinees under the age of 50 , compared to older ones (Kruskal-Wallis test, $p=0.03$ ) (Table 6).

\section{Discussion}

In this study, we have used the EORTC QLQ-BR23 Breast Cancer-Specific Module Questionnaire which focuses on disease-specific factors that contribute to QoL. The results of the research with the EORTC BR23 questionnaire showed that the type of surgery has significant impact on the quality of life of women with breast cancer. The type of surgery, time passed after surgery and adjuvant oncologic therapy, and age of the participants showed poor results of quality of life after breast cancer surgery

Table 3: Values of the QLQ-BR23 scale, 1 month after surgery regarding to the type of procedure

\begin{tabular}{|c|c|c|c|c|}
\hline \multirow{2}{*}{$\begin{array}{l}\text { QLQ-BR23 } \\
1 \text { month after surgery }\end{array}$} & \multicolumn{3}{|c|}{ Median (interquartile range) in regard to the type of procedure } & \multirow[t]{2}{*}{ p-value ${ }^{*}$} \\
\hline & Mastectomy $(n=49)$ & Breast conserving therapy $(n=51)$ & Total & \\
\hline Body image & $62.5(2.1-97.9)$ & $66.7(33.3-91.7)$ & $66.7(33.3-91.7)$ & 0.51 \\
\hline Sexual functioning & $16.7(0-33.3)$ & $83.3(66.7-100)$ & $50(16.7-83.3)$ & $<0.001$ \\
\hline Sexual pleasure & $0(0-33.3)$ & $66.7(66.7-100)$ & $33.3(0-66.7)$ & $<0.001$ \\
\hline Assessment of future & $0(0-33.3)$ & $33.3(0-66.7)$ & $33.3(0-50)$ & 0.27 \\
\hline Side effects of systemic therapy & $38.1(19-52.4)$ & $33.3(7.1-47.6)$ & $33.3(14.3-51.2)$ & 0.04 \\
\hline Symptoms - breast & $33.3(16.7-58.3)$ & $33.3(16.7-50)$ & $33.3(16.7-58.3)$ & 0.62 \\
\hline Symptoms - arm & $44.4(22.2-66.7)$ & $33.3(11.1-55.6)$ & $44.4(22.2-55.6)$ & 0.06 \\
\hline Anxiety due to hair loss & $66.7(33.3-100)$ & $66.7(33.3-66.7)$ & $66.7(33.3-100)$ & 0.38 \\
\hline Functionality scale & $43.8(12.5-61.5)$ & $50(37.5-60.4)$ & $45.8(29.2-60.4)$ & 0.18 \\
\hline Symptoms scale & $42.2(21.1-66.7)$ & $51.1(35-56.1)$ & $48.9(22.2-60)$ & 0.95 \\
\hline
\end{tabular}

*Mann-Whitney U-test. In bold: statistically significant.

Table 4: Values of the QLQ-BR23 scale, 1 year after surgery regarding the type of procedure

\begin{tabular}{|c|c|c|c|c|}
\hline \multirow{2}{*}{$\begin{array}{l}\text { QLQ-BR23 } \\
\text { One year after surgery dana }\end{array}$} & \multicolumn{3}{|c|}{ Median (interquartile range) in regard to the type of procedure } & \multirow[t]{2}{*}{ p-value* } \\
\hline & Mastectomy $(n=50)$ & Breast conserving therapy $(n=51)$ & Total & \\
\hline Body image & $66.7(50-100)$ & $75(50-100)$ & $66.7(50-100)$ & 0.52 \\
\hline Sexual functioning & $16.7(0-33.3)$ & $66.7(66.7-100)$ & $50(16.7-83.3)$ & $<0.001$ \\
\hline Sexual pleasure & $33.3(33.3-66.7)$ & $66.7(66.7-91.7)$ & $66.7(33.3-66.7)$ & 0.04 \\
\hline Assessment of future & $33.3(33.3-66.7)$ & $33.3(0-66.7)$ & $33.3(0-66.7)$ & 0.35 \\
\hline Side effects of systemic therapy & $19(9.5-35.7)$ & $19(9.5-38.1)$ & $19(9.5-36.9)$ & 0.72 \\
\hline Symptoms - breast & $16.7(8.3-33.3)$ & $25(8.3-58.3)$ & $25(8.3-41.7)$ & 0.17 \\
\hline Symptoms - arm & $22.2(0-44.4)$ & $22.2(11.1-55.6)$ & $22.2(11.1-44.4)$ & 0.19 \\
\hline Anxiety due to hair loss & $33.3(0-66.7)$ & $33.3(0-91.7)$ & $33.3(0-66.7)$ & 0.78 \\
\hline Functionality scale & $50(37.5-59.4)$ & $58.3(54.2-79.2)$ & $54.2(39.6-62.5)$ & 0.03 \\
\hline Symptoms scale & $31.1(17.8-38.9)$ & $28.9(15.6-60)$ & $30(17.8-48.3)$ & 0.60 \\
\hline
\end{tabular}


Table 5: QLQ-BR23 scale values, 1 month, and 1 year after surgery regarding the age groups in patients after mastectomy

\begin{tabular}{|c|c|c|c|c|}
\hline \multirow{2}{*}{$\begin{array}{l}\text { Mastectomy } \\
\text { QLQ-BR23 }\end{array}$} & \multicolumn{3}{|c|}{ Median (interquartile range) in regard to age groups } & \multirow[t]{2}{*}{ p-value* } \\
\hline & Up to 50 years & $51-60$ years & 61 and older & \\
\hline \multicolumn{5}{|c|}{ One month after surgery } \\
\hline Body image & $0(0-66.7)$ & $50(0-100)$ & $91.7(66.7-100)$ & 0.006 \\
\hline Sexual functioning & $25(0-33.3)$ & $16.7(0-33.3)$ & $0(0-4.2)$ & 0.03 \\
\hline Sexual pleasure & $16.7(0-75)$ & $0(0-33.3)$ & $0(0-66.7)$ & 0.71 \\
\hline $\begin{array}{l}\text { Assessment of } \\
\text { future }\end{array}$ & $0(0-33.3)$ & $0(0-33.3)$ & $16.7(0-75)$ & 0.46 \\
\hline $\begin{array}{l}\text { Side effects of } \\
\text { systemic therapy }\end{array}$ & $50(23.8-60.7)$ & $33.3(17.9-48.8)$ & $38.1(16.7-57.1)$ & 0.34 \\
\hline $\begin{array}{l}\text { Symptoms - } \\
\text { breast }\end{array}$ & $58.3(27.1-66.7)$ & $25(16.7-41.7)$ & $29.2(16.7-70.8)$ & 0.10 \\
\hline Symptoms - arm & $44.4(22.2-63.9)$ & $44.4(22.2-66.7)$ & $38.9(22.2-69.4)$ & 0.93 \\
\hline $\begin{array}{l}\text { Anxiety due to } \\
\text { hair loss }\end{array}$ & $100(41.7-100)$ & $66.7(33.3-100)$ & $33.3(0-100)$ & 0.27 \\
\hline $\begin{array}{l}\text { Functionality } \\
\text { scale }\end{array}$ & $25(6.3-60.4)$ & $37.5(6.3-58.3)$ & $58.3(41.7-62.5)$ & 0.30 \\
\hline Symptoms scale & $56.7(33.9-67.8)$ & $32.2(16.7-54.4)$ & $40(24.4-73.3)$ & 0.28 \\
\hline \multicolumn{5}{|l|}{ One year after surgery } \\
\hline Body image & $50(33.3-66.7)$ & $66.7(54.2-100)$ & $83.3(64.6-100)$ & 0.05 \\
\hline Sexual functioning & $33.3(16.7-50)$ & $16.7(0-33.3)$ & $0(0-4.2)$ & $<0.001$ \\
\hline Sexual pleasure & $50(33.3-100)$ & $33.3(8.3-58.3)$ & $33.3(16.7-50)$ & 0.26 \\
\hline $\begin{array}{l}\text { Assessment of } \\
\text { future }\end{array}$ & $33.3(33.3-33.3)$ & $50(33.3-66.7)$ & $33.3(25-66.7)$ & 0.36 \\
\hline $\begin{array}{l}\text { Side effects of } \\
\text { systemic therapy }\end{array}$ & $14.3(9.5-19)$ & $9.5(9.5-33.3)$ & $28.6(19-47.6)$ & 0.008 \\
\hline $\begin{array}{l}\text { Symptoms - } \\
\text { breast }\end{array}$ & $25(16.7-33.3)$ & $12.5(8.3-18.8)$ & $25(16.7-41.7)$ & 0.07 \\
\hline Symptoms - arm & $22.2(0-33.3)$ & $22.2(0-52.8)$ & $22.2(8.3-55.6)$ & 0.80 \\
\hline $\begin{array}{l}\text { Anxiety due to } \\
\text { hair loss }\end{array}$ & $50(0-75)$ & $33.3(0-83.3)$ & $33.3(0-66.7)$ & 0.92 \\
\hline $\begin{array}{l}\text { Functionality } \\
\text { scale }\end{array}$ & $50(41.7-57.3)$ & $43.8(37.5-61.5)$ & $50(35.4-63.5)$ & 0.93 \\
\hline Symptoms scale & $18.9(12.8-37.8)$ & $35.6(31.1-48.9)$ & $30(20-40.6)$ & 0.28 \\
\hline
\end{tabular}

on the scales of self-image, sexual functioning, sexual pleasure, side effects of systemic therapy, and anxiety due to hair loss, which is consistent with the results of other studies [21], [22], [23], [24]. The results of a study conducted by Murgic et al. in Croatia showed that the self-image scale was the most affected, while sexual functioning was minimally affected, which is contrary to our research [25]. This study did not include questions about sexual functioning before being diagnosed with breast cancer.

One month after the surgery, women with mastectomy rated their sexual functioning and pleasure in sex significantly worse, while the side effects of systemic therapy were more pronounced compared to women with breast conserving surgery. Concerns about reduced sexual functioning led to emotional difficulties including sadness/depression, body image issues, stigma, and have a negative impact on personal relationships [26], [27], [28]. Bakewell and Volker [29] in their study indicate that surgery and oncological therapy that women received during treatment lead to a decrease in sexual activity. Sexual dysfunction affects as many as $90 \%$ of women treated for breast cancer, it includes a wide range of sexual problems that affect mental and physical functioning [30]. Women reported poorer sexual functioning characterized by lack of sexual interest, inability to relax and enjoy sex, difficulty arousing, and difficulty reaching orgasm [31]. Their sex life was weakened and the reason for this was the loss of interest in sex, changed image of their body, pain, side effects due to therapy (fatigue, nausea, and vomiting), and fear of recurrence of the disease [32], [33].
Table 6: QLQ-BR23 scale values, 1 month, and 1 year after surgery in regard to age groups in participants after quadrantectomy

\begin{tabular}{|c|c|c|c|c|}
\hline \multirow{2}{*}{$\begin{array}{l}\text { Breast } \\
\text { conserving } \\
\text { therapy } \\
\text { QLQ-BR23 }\end{array}$} & \multicolumn{3}{|c|}{ Median (interquartile range) in regard to age groups } & \multirow[t]{2}{*}{ p-value ${ }^{*}$} \\
\hline & Up to 50 years & $51-60$ years & 61 and older & \\
\hline \multicolumn{5}{|c|}{ One month after surgery } \\
\hline Body image & $33.3(33.3-66.7)$ & $75(50-100)$ & $66.7(50-93.8)$ & 0.04 \\
\hline $\begin{array}{l}\text { Sexual } \\
\text { functioning }\end{array}$ & $66.7(66.7-83.3)$ & $83.3(66.7-100)$ & $75(58.3-100)$ & $<0.001$ \\
\hline $\begin{array}{l}\text { Sexual } \\
\text { pleasure }\end{array}$ & $66.7(50-83.3)$ & $66.7(66.7-100)$ & $100(75-100)$ & 0.35 \\
\hline $\begin{array}{l}\text { Assessment of } \\
\text { future }\end{array}$ & $0(0-33.3)$ & $33.3(0-66.7)$ & $33.3(25-66.7)$ & 0.02 \\
\hline $\begin{array}{l}\text { Side effects } \\
\text { of systemic } \\
\text { therapy }\end{array}$ & $26.2(4.8-47.6)$ & $33.3(4.8-42.9)$ & $28.6(14.3-56)$ & 0.51 \\
\hline $\begin{array}{l}\text { Symptoms - } \\
\text { breast }\end{array}$ & $41.7(16.7-58.3)$ & $25(8.3-41.7)$ & $45.8(8.3-50)$ & 0.39 \\
\hline $\begin{array}{l}\text { Symptoms - } \\
\text { arm }\end{array}$ & $27.8(0-47.2)$ & $33.3(11.1-55.6)$ & $44.4(22.2-55.6)$ & 0.28 \\
\hline $\begin{array}{l}\text { Anxiety due to } \\
\text { hair loss }\end{array}$ & $66.7(66.7-100)$ & $16.7(0-58.3)$ & $33.3(33.3-66.7)$ & 0.03 \\
\hline $\begin{array}{l}\text { Functionality } \\
\text { scale }\end{array}$ & $45.8(31.3-52.1)$ & $54.2(45.8-66.7)$ & 95.8 & 0.07 \\
\hline $\begin{array}{l}\text { Symptoms } \\
\text { scale }\end{array}$ & $51.1(47.8-55.6)$ & $30(15-42.5)$ & $51.1(20-60)$ & 0.30 \\
\hline \multicolumn{5}{|c|}{ One year after surgery } \\
\hline Body image & $50(31.3-100)$ & $75(50-100)$ & $95.8(75-100)$ & 0.09 \\
\hline $\begin{array}{l}\text { Sexual } \\
\text { functioning }\end{array}$ & $66.7(50-66.7)$ & $66.7(66.7-100)$ & $100(95.8-100)$ & $<0.001$ \\
\hline $\begin{array}{l}\text { Sexual } \\
\text { pleasure }\end{array}$ & $66.7(66.7-66.7)$ & $66.7(33.3-75)$ & $100(75-100)$ & 0.12 \\
\hline $\begin{array}{l}\text { Assessment of } \\
\text { future }\end{array}$ & $33.3(0-41.7)$ & $33.3(0-66.7)$ & $50(25-66.7)$ & 0.29 \\
\hline $\begin{array}{l}\text { Side effects } \\
\text { of systemic } \\
\text { therapy }\end{array}$ & $19(8.3-28.6)$ & $14.3(9.5-23.8)$ & $23.8(19-45.2)$ & 0.25 \\
\hline $\begin{array}{l}\text { Symptoms - } \\
\text { breast }\end{array}$ & $25(8.3-58.3)$ & $25(8.3-41.7)$ & $41.7(6.3-58.3)$ & 0.86 \\
\hline $\begin{array}{l}\text { Symptoms - } \\
\text { arm }\end{array}$ & $22.2(11.1-30.6)$ & $22.2(11.1-36.1)$ & $50(36.1-61.1)$ & 0.12 \\
\hline $\begin{array}{l}\text { Anxiety due to } \\
\text { hair loss }\end{array}$ & $33.3(0-75)$ & $16.7(0-100)$ & $16.7(0-83.3)$ & 0.98 \\
\hline $\begin{array}{l}\text { Functionality } \\
\text { scale }\end{array}$ & $54.2(33.3-58.3)$ & $62.5(54.2-84.4)$ & $81.3(50-80.2)$ & 0.03 \\
\hline $\begin{array}{l}\text { Symptoms } \\
\text { scale }\end{array}$ & $27.8(13.9-62.2)$ & $22.2(15.6-65.6)$ & $45.6(16.7-67.8)$ & 0.92 \\
\hline
\end{tabular}

In this study, 1 year after the surgery and oncological therapy, there was no improvement in the results. Women who have had a mastectomy rated their sexual function worse and enjoyed sex less than women who have had a breast conserving surgery.

Nausea, hair loss, and weight gain due to chemotherapy, discomfort and physical changes from surgery and postmenopausal symptoms, and mood swings due to endocrine therapy can negatively affect sexual functioning and pleasure in sex [34], [35].

Research has shown that hair loss caused by chemotherapy is experienced by women as a major trauma. Hair is an important aspect of self-image and hair loss can be a mental and physical burden. The incidence of alopecia is extremely high and currently ranks third among the most common side effects of chemotherapy immediately after nausea and vomiting [36], [37], [38], [39] . The results of other studies showed that women used make-up, prostheses, wigs, scarves and veils to cover up their physical shortcomings, and some of the women opted for breast reconstruction [40], [41]. In this study, the results showed that hair loss decreased during follow-up 1 year after the end of chemotherapy. In our research, most women were treated with chemotherapy (63.7\%) which led to a higher rate of psychosexual disorders due 
to chemotherapy, which is consistent with the results of other studies [42], [43]

The results in this study show that women who have had a mastectomy have a negative impact on their self-image 1 month after the operation, especially women over the age of 50 , compared to older women, while sexual functioning was assessed poorer by women in the age group of 61 years and older. In a study conducted by Engel et al., women who underwent mastectomy in the younger age group had poorer body image (felt less attractive, disliked their appearance, did not feel whole, were dissatisfied with breasts and scarring), even 2 years after being diagnosed with breast cancer [44]. These changes in appearance can negatively affect their image of their body. Body image is a multidimensional construct and encompasses cognitive, behavioral, and affective aspects [45]. Positive or negative adjustment after mastectomy depends on various psychosocial factors. One of the most important changes is the body image. Women who were treated for breast cancer and who lost their breasts had to deal with the tension and mismatch between "self and body" and the social expectations of femininity [46], [47], [48].

In premenopausal women with breast cancer, sexual functioning and fertility become a challenge due to adjuvant oncologic therapy that affects sexual function and fertility and ovarian suppression [49].

In our research, women stated that physical appearance is important to them, that if they were familiar with breast reconstruction, more than half of the surveyed women would agree to breast reconstruction if the surgeon recommended it. The goal of breast reconstruction is to restore the contour of the body and to improve the image of oneself. Breast reconstruction helps women who have had a mastectomy to improve their quality of life, integrity, and self-image. Breast reconstruction after mastectomy results in a good or very good quality of life and is associated with physical, mental, and social functioning [50]. Women under the age of 50 are the strongest predictor for breast reconstruction. [31], [50], [51].

Sexual functioning and side effects of systemic therapy in this study were worse assessed by women in the age group of 61 years and older, 1 year after mastectomy compared to women who underwent BCT.

Women who were in the older age group reported having had more sexual problems due to breast cancer, had more comorbidities present which negatively affected quality of life outcomes [52], [53]. In a group with BCT, women up to age of 50 rated poor body image a month after surgery, while sexual functioning was significantly better in women aged 51-60 years. Women under the age of 50 were the least concerned about their future, but they are significantly worried about hair loss. BCT as a type of surgery can leave a scar on the breast, deformity of the breast, lymphedema of the arm which can limit the movement and flexibility of the arm. Partners are reluctant to touch the affected breast for fear of pain. This discomfort can be interpreted by a woman as rejection due to scarring, deformity or absence of the breast which can have emotional consequences related to the image of self, both for the woman and for her partner.

One year after surgery, women aged 61 and over assess their sexual functioning better than younger women after BCT.

The results of our study indicate that women with breast cancer who have undergone mastectomy face an increased risk of sexual dysfunction, especially women of younger age groups, and have more problems such as body image disorder, anxiety, therapy side effects, dissatisfaction in relationships and fear of return of the disease, and younger women reported poorer sexual function scores than older women with breast cancer [54], [55].

Chemotherapy, endocrine therapy, surgeries, and radiation can all have a large effect on women's sexual functioning [56]. Breast cancer is now being diagnosed in its earlier stages; BCS is an alternative to mastectomy in patients with lower-stage cancers, the type of chemotherapy, dosage, as well as treatment frequency and duration, would influence the seriousness of the side effects [24]. A meta-analysis of current literature to determine whether mastectomy and BCT induce different outcomes in quality of life highlighted that BCT was preferred over mastectomy because BCT leads to better outcomes in body image, future perspectives, and less systemic side effects [24] which have an effect on sexual functioning and sexual pleasure.

This study has some limitations. The study was cross-sectional so we could not establish a cause and effect relationship. The patients were treated in one health facility. It is recommended that future studies cover more regions in Croatia and include a larger sample to conduct a qualitative study and assess the needs of women after breast cancer treatment and achieve a better QLQ. We used only one quality of life assessment questionnaire, QLQ-BR23 which is a specific module for breast cancer that has its limitations. We did not collect data on whether the comorbidity of the disease had an impact on quality of life, what types of treatment were administered, and to what extent this affected quality of life and sexual functioning in our women. The percentage of those women who did not respond about sexual activity and partnerships is unknown. The studied sample included only women after breast cancer surgery and did not include healthy individuals. A study with healthy control of women and women with breast cancer is a study that is planned to be conducted. 


\section{Conclusion}

Results of this study show that women after breast conserving surgery have better quality of life and less side effects of systemic therapy compared to women after mastectomy.

Sexual functioning, sexual pleasure, body image, systemic therapy side effects, anxiety due to hair loss, and assessment of future were major subscales with significantly lower results with impact on quality of life of women with breast cancer. Patient's age had significant impact on quality of life. Younger women rated quality of life lower in subscales of EORTC QLQ BR 23 questionnaire. Sexual functioning is better in women after breast conserving surgery compared to women after mastectomy.

\section{References}

1. Jemal A, Bray F, Center MM, Ferlay J, Ward E, Forman D. Global cancer statistics. CA Cancer J Clin. 2011;61(2):69-90. https://doi.org/10.3322/caac.20107

PMid:21296855

2. Croatian Institute of Public Health. Croatian National Cancer Registry. Cancer Incidence in Croatia 2015; 2018. Available from: $\quad$ https://www.hzjz.hr/wp-content/uploads/2018/03/ Bilten_2015_rak_final.pdf. [Last accessed on 2020 Jun 18].

3. Yang $Y$, Liu L, Wang $Y$, Wu H, Yang $X$, Wang J, et al. The prevalence of depression and anxiety among Chinese adults with cancer: A systematic review and meta-analysis. BMC Cancer. 2013;13:393. https://doi.org/10.1186/1471-2407-13-393

4. Cheung KL. Treatment strategies and survival outcomes in breast cancer. Cancers (Basel). 2020;12(3):735. https://doi. org/10.3390/cancers 12030735

PMid:32244985

5. Groenvold M. Health-related quality of life in early breast cancer. Dan Med Bull. 2010;57(9):B4184.

PMid:20816024

6. Teo I, Reece GP, Christie IC, Guindani M, Marky MK, Heinberg LJ, et al. Body image and quality of life of breast cancer patients: Influence of timing and stage of breast reconstruction. Psychooncology. 2016;25(9):1106-12. https://doi.org/10.1002/ pon.3952

PMid:26360810

7. Archangelo SC, Sabino Neto M, Veiga DF, Garcia EB, Ferreira LM. Sexuality, depression and body image after breast reconstruction. Clinics (Sao Paulo). 2019;74:e883. https://doi. org/10.6061/clinics/2019/e883

PMid:31166474

8. Montazeri A. Health-related quality of life in breast cancer patients: A bibliographic review of the literature from 1974 to 2007. J Exp Clin Cancer Res. 2008;27(1):32. https://doi. org/10.1186/1756-9966-27-32 PMid:18759983

9. The WHOQOL Group. Development of the World Health Organization WHOQOL-BREF quality of life assessment. Psychol Med. 1998;28(3):551-8. https://doi.org/10.1017/ s0033291798006667

\section{PMid:9626712}

10. Fang $S$, Shu B, Chang $Y$. The effect of breast reconstruction surgery on body image among women after mastectomy: A meta-analysis. Breast Cancer Res Treat. 2013;137(1):13-21. https://doi.org/10.1007/s10549-012-2349-1 PMid:23225142

11. Fobair P, Stewart SL, Chang S, D'Onofrio C, Banks, PJ, Bloom JR. Body image and sexual problems in young women with breast cancer. Psychooncology. 2006;15(7):579-94. https:// doi.org/10.1002/pon.991

PMid: 16287197

12. Baucom DH, Porter LS, Kirby JS, Gremore TM, Keefe FJ. Psychosocial issues confronting young women with breast cancer. Breast Disease. 2006;23:103-13. https://doi. org/10.3233/bd-2006-23114

13. Henson HK. Breast cancer and sexuality. Sex Disabil. 2002;20(4):261-75. https://doi.org/10.1023/A:1021657413409

14. Howes BH, Watson DI, Xu C, Fosh B, Canepa M, Dean NR. Quality of life following total mastectomy with and without reconstruction versus breast-conserving surgery for breast cancer: A case-controlled cohort study. J Plast Reconstr Aesthet Surg. 2016;69(9):1184-91. https://doi.org/10.1016/j. bjps.2016.06.004

PMid:27406255

15. Gilbert E, Ussher JM, Perz J. Sexuality after breast cancer: A review. Maturitas. 2010;66(4):397-407. https://doi. org/10.1016/j.maturitas.2011.07.022 PMid:20439140

16. Sprangers MA, Groenvold M, Arraras JI, Franklin J, te Velde A, Muller M, et al. The EORTC breast cancer-specific quality-oflife questionnaire module: First results from a three-country field study. J Clin Oncol. 1996;14(10):2756-68. https://doi. org/10.1200/jco.1996.14.10.2756

PMid:8874337

17. Clinical Trial Database. EORTC. Available from: Available from https://www.eortc.org/research_field/clinical-detail/15931. [Last accessed on 2020 Jun 18].

18. Pačarić $\mathrm{S}$, Kristek $\mathrm{J}$, Mirat $\mathrm{J}$, Kondža $\mathrm{G}$, Turk T, Farčić $\mathrm{N}$, et al. The quality of life of Croatian women after mastectomy: A cross-sectional single-center study. BMC Public Health. 2018;18(1):1-8. https://doi.org/10.1186/s12889-018-5929-0 PMid:30097040

19. Dujmović A, Marčinko D, Bulić K, Kisić $H$, Duduković $M$, Mijatović D. Quality of Life and depression among female patients undergoing surgical treatment for breast cancer: A prospective study. Psychiatr Danub. 2017;29(3):345-50 https://doi.org/10.24869/psyd.2017.345

20. Fayers PM, Aaronson NK, Bjordal K, Groenvold M, Curran D, Bottomley A, On Behalf of the EORTC Quality of Life Group. The EORTC QLQ-C30 Scoring Manual. Brussels: European Organisation for Reasearch and Treatmenr of Cancer; 2001.

21. Kostić S, Murtezani Z, Andrić Z, Ivanović N, Kozomarall Z, Kostić $\mathrm{M}$, et al. Assessment of age-related influences on the quality of life of breast cancer patients before and after surgical treatment. Vojnosanitetski Pregled. 2020;2020:155. https://doi. org/10.2298/vsp180629155k

22. Liu Y, Xin T, Huang DY, Shen WX, Li L, Lv YJ, et al. Prognosis in very young women with triple-negative breast cancer: Retrospective study of 216 cases. Med Oncol. 2014;31:222. https://doi.org/10.1007/s12032-014-0222-2

23. Bantema-Joppe E, de Bock G, Woltman-van lersel M, Busz DM Ranchor AV, Langendijk JA, et al. The impact of age on changes in quality of life among breast cancer survivors treated with breast-conserving surgery and radiotherapy. $\mathrm{Br} \mathrm{J}$ Cancer. 2015;112(4):636-43. https://doi.org/10.1038/bjc.2014.632 


\section{PMid:25602967}

24. Ng ET, Ang RZ, Tran BX, Ho CS, Zhang Z, Tan W, et al Comparing quality of life in breast cancer patients who underwent mastectomy versus breast-conserving surgery: A meta-analysis. Int J Environ Res Public Health. 2019;16(24):4970. https://doi. org/10.3390/ijerph16244970

\section{PMid:31817811}

25. Murgić J, Soldić Ž, Vrljić D, Samija I, Kirac I, Bolanca A. Quality of life of Croatian breast cancer patients receiving adjuvant treatment--comparison to long-term breast cancer survivors. Coll Antropol. 2012;36(4):1335-41.

PMid:23390830

26. Sharma N, Purkayastha A. Factors affecting quality of life in breast cancer patients: A descriptive and cross-sectional study with review of literature. J Midlife Health. 2017;8(2):75-83. https://doi.org/10.4103/jmh.jmh_15_17 PMid:28706408

27. Kim J, Han JY, Shaw B, McTavish F, Gustafson D. The roles of social support and coping strategies in predicting breast cancer patients' emotional well-being: Testing mediation and moderation models. J Health Psychol. 2010;15:543-52. https:// doi.org/10.1177/1359105309355338

\section{PMid:20460411}

28. Kroenke $\mathrm{CH}$, Quesenberry C, Kwan ML, Sweeney C, Castillo A Caan BJ. Social networks, social support, and burden in relationships, and mortality after breast cancer diagnosis in the life after breast cancer epidemiology (LACE) study. Breast Cancer Res Treat. 2013;137(1):261-71. https://doi.org/10.1007/ s10549-012-2253-8

PMid:23143212

29. Bakewell RT, Volker DL. Sexual dysfunction related to the treatment of young women with breast cancer. Clin J Oncol Nurs. 2005;9(6):697-702. https://doi.org/10.1188/05.cjon.697-702 PMid:16381545

30. Wang F, Chen F, Huo X, Xu R, Wu L, Wang J, et al. A neglected issue on sexual well-being following breast cancer diagnosis and treatment among Chinese women. PLoS One. 2013;8(9):e74473. https://doi.org/10.1371/journal. pone. 0074473

PMid:24086349

31. Iskandar ME, Dayan E, Lucido D. Factors influencing incidence and type of postmastectomy breast reconstruction in an urban multidisciplinary cancer center. Plast Reconstr Surg. 2015;135(2):270e-6. https://doi.org/10.1097/ prs. 0000000000000888

32. Morrow M, Scott SK, Menck HR, Mustoe TA, Winchester DP. Factors influencing the use of breast reconstruction postmastectomy: A national cancer database study. J Am Coll Surg. 2001;192(1):1-8. https://doi.org/10.1016/ s1072-7515(00)00747-x

PMid:11192909

33. Sisco M, Du H, Warner JP, Howard MA, Winchester DP, Yao K. Have we expanded the equitable delivery of postmastectomy breast reconstruction in the new millennium? Evidence from the national cancer data base. J Am Coll Surg. 2012;215(5):658-66. https://doi.org/10.1016/j.jamcollsurg.2012.07.008 PMid:22921327

34. Shahhosseini Z, Gardeshi ZH, Pourasghar M, Salehi F. A review of affecting factors on sexual satisfaction in women. Mater Sociomed. 2014;26(6):378-81. https://doi.org/10.5455/ msm.2014.26.378-381

35. Enien MA, Ibrahim N, Makar W, Darwish D, Gaber M. Healthrelated quality of life: Impact of surgery and treatment modality in breast cancer. J Can Res Ther. 2018;14(5):9557-63. https:// doi.org/10.4103/0973-1482.183214

\section{PMid:30197331}

36. Choi EK, Kim IR, Chang O, Kang D, Nam SJ, Lee JE, et al Impact of chemotherapy-induced alopecia distress on body image, psychosocial well-being, and depression in breast cancer patients. Psychooncology. 2014;23(10):1103-10. https:// doi.org/10.1002/pon.3531

PMid:24664939

37. Werbel T, Cohen PR. Persistent alopecia in a breast cancer patient following taxane chemotherapy and adjuvant endocrine therapy: Case report and review of post-treatment hair loss in oncology patients with breast cancer. Cureus. 2018;10(7):e3056. https://doi.org/10.7759/cureus.3056

PMid:30280054

38. Harcourt D, Frith H. Women's experiences of an altered appearance during chemotherapy: An indication of cancer status. J Health Psychol. 2008;13(5):597-606. https://doi. org/10.1177/1359105308090932

PMid: 18519434

39. Merchant TE, McCormick B, Yahalom J, Borgen P. The influence of older age on breast cancer treatment decisions and outcome. Int J Radiat Oncol Biol Phys. 1996;34(3):565-70. https://doi. org/10.1016/0360-3016(95)02167-1

PMid:8621279

40. Brunet J, Sabiston CM, Burke S. Surviving breast cancer: Women's experiences with their changed bodies. Body Image. 2013;10(3):344-51. https://doi.org/10.1016/j. bodyim.2013.02.002

PMid:23490552

41. Jassim GA, Whitford DL. Quality of life of Bahraini women with breast cancer: A cross sectional study. BMC Cancer. 2013;13:212. https://doi.org/10.1186/1471-2407-13-212

42. Arora NK, Gustafson DH, Hawkins RP, McTavish F, Cella DF, Pingree $\mathrm{S}$, et al. Impact of surgery and chemotherapy on the quality of life of younger women with breast carcinoma: A prospective study. Cancer. 2001;92:1288-98. https:// doi.org/10.1002/1097-0142(20010901)92:5<1288:aidcncr1450>3.0.co;2-e

PMid: 11571745

43. Schover LR. Counseling cancer patients about changes in sexual function. Oncology (Williston Park). 1999;13(11):1585-91. PMid:10581604

44. Engel J, Kerr J, Schlesinger-RaabA, Sauer H, Hölzel D. Quality of life following breast-conserving therapy or mastectomy: Results of a 5-year prospective study. Breast J. 2004;10(3):223-31. https://doi.org/10.1111/j.1075-122x.2004.21323.x PMid: 15125749

45. Cash TF, Smolak L. Body Image: A Handbook of Science, Practice, and Prevention. New York: Guilford Press; 2011.

46. Sherman KA, Woon S, French J, Elder E. Body image and psychological distress in nipple-sparing mastectomy: The roles of self-compassion and appearance investment. Psychooncology. 2017;26(3):337-45. https://doi.org/10.1002/ pon. 4138

PMid:27167009

47. Grogan S, Mechan J. Body image after mastectomy: A thematic analysis of younger women's written accounts. J Health Psychol. 2017;22(11):1480-90. https://doi. org/10.1177/1359105316630137 PMid:26916388

48. Sun L, Ang E, Ang WH, Lopez V. Losing the breast: A metasynthesis of the impact in women breast cancer survivors. Psychooncology. 2018;27(2):376-85. https://doi.org/10.1002/ pon. 4460

PMid:28544436 
49. Ahmed S, Iqbal N, Emara M, Le D. Effect of surgery and adjuvant therapy in reproductive and sexual dysfunction in premenopausal women with breast cancer. Reprod Syst Sex Disord. 2016;5(2):169. https://doi.org/10.4172/2161-038x.1000169

50. Paredes CG, de Pinho Pessoa SG, Teles DT, de Amorim DN, Araújo Silveira J, Barreto Araujo PR. The impact of breast reconstruction on the quality of life of patients after mastectomy at the plastic surgery service of Walter Cantídio university hospital. Rev Bras Cir Plást. 2013;28(1):100-4. https://doi. org/10.1590/s1983-51752013000100017

51. Butler PD, Nelson JA, Fischer JP. Racial and age disparities persist in immediate breast reconstruction: An updated analysis of 48,564 patients from the 2005 to 2011 American college of surgeons national surgery quality improvement program data sets. Am J Surg. 2016;212(1):96-101. https://doi.org/10.1016/j. amjsurg.2015.08.025

PMid:26545345

52. Ganz PA, Schag AC, Lee JJ, Polinsky ML, Tan SJ. Breast conservation versus mastectomy. Is there a difference in psychological adjustment or quality of life in the year after surgery? Cancer. 1992;69(7):1729-38. https:// doi.org/10.1002/1097-0142(19920401)69:7<1729:aid- cncr2820690714>3.0.co;2-d

PMid:1551058

53. Cobo-Cuenca Al, Martin-Espinosa NM, Sampietro-Crespo A Rodriguez-Borrego MA, Carmona-Torres JM. Sexual dysfunction in Spanish women with breast cancer. PLoS One. 2018;13(8):e0203151. https://doi.org/10.1371/journal. pone. 0203151

PMid:30169506

54. Avis NE, Crawford S, Manuel J. Psychosocial problems among young women with breast cancer. Psychooncology. 2004;13(5):295-308. https://doi.org/10.1002/pon.744 PMid: 15133771

55. Ljungman L, Ahlgren J, Petersson LM, Flynn KE, Weinfurt K, Gorman JR, et al. Sexual dysfunction and reproductive concerns in young women with breast cancer: Type, prevalence, and predictors of problems. Psychooncology. 2018;27(12):2770-7. https://doi.org/10.1002/pon.4886 PMid:30203884

56. Boswell EN, Dizon DS. Breast cancer and sexual function. Transl Androl Urol. 2015;4(2):160-8.

PMid:26816822 